\title{
Współczesny dyskurs o urokach na przykładzie poradników Uzdrowicielki syberyjskiej
}

\author{
Joanna Rybarczyk-Dyjewska iD https://orcid.org/0000-0002-8414-9421 \\ Instytut Filologii Wschodniosłowiańskiej \\ Uniwersytet Jagielloński \\ e-mail: joanna.rybarczyk@uj.edu.pl
}

\section{Abstract \\ Contemporary Discourse on Spells on the Example of the Siberian Healer's Handbooks}

The aim of the article is to present the most characteristic elements of the contemporary Russian discourse on spells. The empirical material used here was based on magical handbooks and spell collections by Natalia Ivanova Stiepanova, who calls herself (coming from a well-known house of folk healers) the Healer from Siberia. The paper explains the genesis of Russian people's sensibility to all signs of esotericism and shows huge popularity of magical practices in contemporary Russia. The paper also highlights mutual relations between magic, science and religion taking place in these areas (nowadays and in the past). The analysis of the material has shown that Russians today are firmly convinced of the existence of charms (bad spells cast with glances or words) which may cause various misfortunes. It is equally popular among them to believe that with the help of appropriate - as suggested by Stiepanova - magical rituals, a bad spell can be undone (got rid of).

Keywords: magic, religion, spell, discourse, magical handbooks

Słowa kluczowe: magia, religia, urok, dyskurs, poradniki magiczne

Wydawać by się mogło, że we współczesnej rzeczywistości, gdzie niemal wszystko zostało już zbadane i opisane przez naukę, nie ma miejsca na wiarę w sprawczą moc magii.

Okazuje się jednak, że świat XXI wieku nie jest zupełnie „odczarowany”, gdyż ludzie wciąż chętnie i całkiem świadomie odwołują się do wierzeń typowych dla kultur pierwotnych. 
Tym samym postawienie wyraźnej granicy między magią, religią a racjonalnością nie jest możliwe. Trudno się oprzeć wrażeniu, iż ludzkość potrzebuje wszystkich trzech sposobów „wyjaśniania świata”, by w sytuacjach kryzysowych ograniczyć poczucie bezsilności.

Uczeni od dziesięcioleci próbują bez większego powodzenia rozgraniczyć magię, naukę i religię. Na przykład Zuzanna Grębecka zauważa, że wypada się zgodzić z Clyde'em Kluckhohnem, który twierdził, że „każdy może stworzyć definicję, która odróżni magię od religii, ale nikt dotąd nie stworzył takiej, którą inni uczeni by zaakceptowali: zawartość treściowa tych pojęć po prostu za bardzo się różni"1. W tradycji wschodniosłowiańskiej - ze względu na zjawisko dwuwiary - kwestia przenikania się religii i magii jest szczególnie ciekawa i aktualna. Badacze, w tym także duchowni, podkreślają, że w Rosji magia tak naprawdę nigdy nie zniknęła i Rosjanie, poszukując rozwiązania swoich problemów, wykorzystują dziś często potencjał obu systemów: magicznego i religijnego. Jako przyczynę wrażliwości naszych wschodnich sąsiadów na ezoterykę naukowcy wskazują wydarzenia historyczne, jakie nastąpiły po 1917, a potem po 1991 roku. W rezultacie przemian kulturowo-politycznych związanych najpierw z rewolucją (walka z religią i powszechny ateizm), a następnie z rozpadem ZSRR (załamanie dotychczasowego systemu wartości i konieczność poszukiwania nowej tożsamości), Rosja zaczęła stanowić wyjątkowo podatny grunt do powstania rozmaitych ruchów religijnych i sekt oraz rozwoju zainteresowania okultyzmem, magią i astrologią. $\mathrm{W}$ opinii niektórych autorów dla rozpowszechnienia magii wśród Słowian wschodnich oraz jej związków z religią nie bez znaczenia była specyfika dominującego na tych terenach wyznania prawosławnego, które cechuje większa niż w przypadku katolicyzmu mistyczność

W literaturze antropologicznej magia bywa nazywana „bękarcią siostrą nauki”. Wynika to z faktu, że magia i nauka nieraz przenikały się wzajemnie (m.in. w postaci alchemii czy astrologii) i nadal przenikają, co owocuje rozmaitymi próbami unaukowienia magii. José Luis Barceló przewidywał, że magia, choć może się to wydać paradoksem, z czasem zyska na racjonalności, co pomoże w znalezieniu, albo raczej

${ }^{1}$ Z. Grębecka, Stowo magiczne poddane technologii. Magia ludowa w praktykach postsowieckiej kultury popularnej, Kraków 2006, s. 23. Podejmując temat wzajemnych relacji magii i religii, uczeni często wskazują na tzw. momenty magiczne w religii i na podobną w obu systemach sakralną funkcję języka. Zob. S.J. Tambiah, Magia, nauka, religia a zakres racjonalności, thum. B. Hlebowicz, Kraków 2007; M. Weber, Szkice z socjologii religii, thum. J. Prokopiuk, H. Wandowski, Warszawa 1995; A. Brzozowska-Krajka, Między magia a religia. O modlitewkach ludowych, [w:] Folklor - sacrum - religia, J. Bartmiński, M. Jasińska-Wojtkowska (red.), Lublin 1995, s. 183-200; Û.V. Ermolina, Magiâ kak kul'turno-religioznyj fenomen, avtoreferat dissertacii na soisk. učënoj stepeni kandidata filosofskih nauk, Orël 2009, https:/www.dissercat.com/content/magiya-kak-kulturno-religioznyi-fenomen/read [dostęp: 1.06.2019]; W.J. Burszta, Od mowy magicznej do szumów popkultury, Warszawa 2009; M. Buchowski, Magia. Jej funkcje i struktura, Poznań 1986.

2 Zob. A. Gołębiowska-Suchorska, „Poproś wodę o pieniadze”. Tradycja znachorska we współczesnych poradnikach magicznych $w$ Rosji, „Lud. Organ Polskiego Towarzystwa Ludoznawczego i Komitetu Nauk Etnologicznych PAN” 2015, t. 49, s. 209-211; Z. Grębecka, Charakterystyka terenu badań oraz wirtualnej przestrzeni funkcjonowania magii, [w:] eadem, Stowo magiczne..., op. cit., s. 125-151; V. Tarnavskyi, Dzieci swoich czasów. Ruchy młodzieżowe w Rosji a zmiany kulturowe po upadku ZSRR, Warszawa 2007; O.B. Hristoforova, Kolduny i žertvy. Antropologiâ koldovstva v sovremennoj Rossii, Moskva 2010. 
wyjaśnieniu, jej podstawowych praw i fundamentów. Tendencja do racjonalizowania magii - pisze Barceló - wynika z tego, że współczesny człowiek, próbując ogarnąć rozumem materię, jaka została mu podana, coraz częściej stwierdza, że w dzisiejszym świecie niewiele jest rzeczy naprawdę racjonalnych i logiczne rozumowanie nie wystarcza. Ludzie zmieniają więc kurs i zwracają się ku rzeczom, które jeśli nawet przeczą zdrowemu rozsądkowi, to zapewniają im przynajmniej jakąś odmianę, na dodatek w wielu przypadkach pozytywną ${ }^{3}$ I rzeczywiście, trudno się nie zgodzić, że obecnie mamy do czynienia (szczególnie w Rosji) ze swoistym renesansem magii, która śmiało wkracza na niespotykane dotąd obszary - także w świat nauki i technologii. Grębecka konstatuje, że dla społeczeństw postradzieckich charakterystyczne jest bezgraniczne i irracjonalne zaufanie do nauki. Tendencja ta miała swoje korzenie w czasach radzieckich, kiedy na szeroką skalę prowadzono walkę z religią przez propagandę racjonalności. Masom próbowano wówczas wpoić nie tyle przekonanie, że w pewne rzeczy nie można wierzyć, ile przeświadczenie, że wiarę trzeba unaukowić, podbudować teoriąa . Aktualność tego poglądu potwierdzają obserwacje Agnieszki Gołębiowskiej-Suchorskiej, która zauważa, iż sposób prezentowania relacji naukamagia we współczesnych rosyjskich poradnikach magicznych sugeruje odkrycie naukowych podstaw magii, czyli ujawnienie zasad od wieków rządzących działaniami znachorów, choć przez nich nieuświadamianych. Owo unaukowienie ma za zadanie odpierać oskarżenia wysuwane wobec praktyk magicznych jako działań o konotacjach negatywnych ${ }^{5}$.

Można zatem zaryzykować stwierdzenie, że w Rosji magia stanowi nieodłączny element rzeczywistości (zarówno wirtualnej, jak i realnej) i zajmuje istotne miejsce w życiu codziennym wielu Rosjan. Świadczy o tym ogromna liczba publikacji o tematyce ezoterycznej, popularność specjalistycznych gabinetów oferujących usługi magiczne oraz wszechobecna reklama tych usług ${ }^{6}$.

Celem niniejszego artykułu jest próba spojrzenia na to zjawisko z perspektywy językowej i przedstawienie najbardziej charakterystycznych elementów współczesnego rosyjskiego dyskursu o urokach. W charakterze materiału empirycznego wykorzystam poradniki magiczne autorstwa tak zwanej Uzdrowicielki syberyjskiej ( $s y$ birskaâ celitiel'nica), czyli Natalii Iwanownej Stiepanowej, która prowadzi szeroko zakrojoną działalność magiczną - zarówno w sieci, jak i na rynku wydawniczym7

3 J.L. Barceló, Czarna magia w XX wieku, tłum. Z. Siewak-Sojka, Warszawa 1991, s. 19-21, 140.

${ }^{4}$ Z. Grębecka, op. cit., s. 174. Co ciekawe, w charakteryzowanym dalej materiale językowym znajdujemy określenie „nauka”, które odnosi się do magii właśnie.

5 A. Gołębiowska-Suchorska, Od znachorki do autorki. Rosyjska tradycja znachorska we wspótczesnych poradnikach magicznych, Bydgoszcz 2016, s. 123. Zob. także: A. Crowley, Magija w teorii i praktyce, tłum. M. Uniejski, Katowice 1998; E.V. Subbotskij, Neuničtožimost'volšebnogo: kak magiâ i nauka dopolnâut drug druga v sovremennoj žizni, Moskva-Berlin 2015.

${ }^{6}$ Zob. m.in. pozycje dostępne w księgarni internetowej Ozon w dziale „Ėzoterika i spiritizm”, w którym osobno wydzielone są publikacje z kategorii „Magiâ. Koldovsto”, https://www.ozon.ru/category/ezoterika-i-spiritizm-40016/?nonfictionbookgenre=135749 [dostęp: 1.06.2019]; oraz witryny, które pojawiają się po wpisaniu w wyszukiwarkę internetową hasła „magičeskie uslugi”, http://www.elena-mag.ru/uslugi/ [dostęp: 1.06.2019].

${ }^{7}$ Oficjalna strona Uzdrowicielki: http://www.magia21.ru [dostęp: 1.06.2019]. W dalszych rozważaniach wykorzystuję następujące pozycje autorstwa Stiepanowej: N.I. Stepanova, Ot porči i sglaza, 
Stiepanowa nazywana bywa legendą rosyjskiego internetu, uzdrowicielką, wróżką, czarodziejką. Jest autorką wielu prac: zbiorów zaklęć, poradników, kalendarzy, a także materiałów publikowanych w gazecie „Magiâ i žizn"”. Istotną dla dalszych rozważań cechą tych publikacji jest dialogowość. Przejawia się ona tym, że na łamach poradników, przez korespondencję, Uzdrowicielka prowadzi ciągłą rozmowę ze swoimi czytelnikami uczniami. Listy przypominają wymianę myśli bliskich sobie osób, które darzą się wzajemnym zaufaniem. Ich adresatka (odpowiadając na list, zmienia się w nadawcę) staje się powiernikiem, który „wysłuchuje”, doradza i pociesza. Gołębiowska-Suchorska zauważa, iż listy klientów, często błagalne, adresowane do współczesnych znachorek, wpisują się w charakterystyczną dla społeczeństwa rosyjskiego tradycję pisemnego zwracania się o pomoc do wyższych instancji. Niektórzy badacze dostrzegają w tym epistolograficznym dialogu obywateli z władzą fenomen kulturowy, odróżniający współczesną Rosję od krajów zachodnich, w których ten sposób apelacji do władz nigdy nie był prowadzony na tak dużą skalę. Przy czym instancjami takimi okazują się przedstawiciele triady światopoglądowej: magia - reprezentowana przez współczesną znachorkę lub maga, religia - w osobie świętego, i nauka, stanowiąca racjonalną podstawę ideologiczną władzy państwowej. Różnice pomiędzy magią, religią i władzą świecką nie wykluczają przy tym podobieństw funkcjonalnych - wszystkie mają moc sprawczą większą niż jednostka ${ }^{8}$.

W tym miejscu wypada wspomnieć o tytułowym dyskursie. Pojęcia dyskurs używa obecnie wiele dyscyplin i ma ono liczne oraz zróżnicowane zastosowania w potocznej polszczyźnie. Dyskurs jest również kategorią niezwykle popularną w językoznawstwie, gdzie bywa dyskutowana między innymi kwestia wydzielania i opisywania różnych jego typów. Niektóre z nich (na przykład polski i rosyjski dyskurs polityczny) doczekały się już wielu wartościowych opracowań9 ${ }^{9}$ Inne - jak choćby dyskurs ezoteryczny - wciąż wymagają badań ${ }^{10}$. W rozważaniach nad dys-

Moskva 2016; eadem, Zaŝitnâ̂ kniga - kalendar'. Zagovory i oberegi na každyj den', Moskva 2008; eadem, 1777 novyh zagovorov sibirskoj celitel'nicy, Moskva 2013; eadem, Tajnaâ kniga znaharâ, Moskva 2017; eadem, Ot porči, sglaza, i proklâtiâ, Moskva 2017; eadem, Zagovory sibirskoj celitel'nicy, Moskva 2011; eadem, 909 zagovorov sibirskoj celitel'nicy, Moskva 2011.

8 A. Gołębiowska-Suchorska, Od znachorki..., op. cit., s. 69-82.

${ }^{9}$ Zob. Rytualny chaos. Studium dyskursu publicznego, M. Czyżewski, S. Kowalski, A. Piotrowski (red.), Warszawa 2010; O.L. Mihaleva, Političeskij diskurs. Specifika manipulâtivnogo vozdejstviâ, Moskva 2009.

${ }^{10}$ Podjęta przeze mnie tematyka wpisuje się w badania nad szeroko rozumianym dyskursem ezoterycznym. Ezoterykę najogólniej definiuje się jako „wiedzę tajemną, przeznaczoną tylko dla grona wtajemniczonych, wybrańców; przeciwieństwo wiedzy egzoterycznej” (Ezoteryczna wiedza, [w:] B. Petrozolin-Skowrońska (red.), Encyklopedia popularna PWN, Warszawa 1994, s. 218). Bernhard Grom podkreśla, że charakterystyczną cechą współczesnego ezoteryzmu jest ambicja bycia systemem poznania rzeczywistości i w takim ujęciu jako ezoteryczne trzeba określić wszystkie te kierunki, które lokują się poza głównym nurtem myślenia naukowego oraz światopoglądowego i pomijają kryteria racjonalizmu, pretendując do szczególnego, wyższego poznania (B. Grom, Ezoteryzm - nowa nadzieja?, tłum. U. Popławska, Kraków 2006, s. 11-12). Agnieszka Kowalczewska z kolei zauważa, iż współcześnie mamy do czynienia z osobliwym renesansem - mniej lub bardziej poważnych - zainteresowań różnymi postaciami wiedzy tajemnej, która w rezultacie stała się skomercjalizowana, jest towarem i jednocześnie elementem kultury masowej (A. Kowalczewska, Ezoteryka na sprzedaż, Warszawa 2001, s. 7-13). Podobne wnioski wysuwa Agnieszka Gołębiowska-Suchorska, która pisze, że zaklęcia zawarte we współczesnych poradnikach magicznych stanowią produkt komercyjny. W związku z tym publikacje te należy traktować jak 
kursem jedną z aktualnych i często przywoływanych teorii jest, bliska także mnie, koncepcja Teuna van Dijka. Ten holenderski językoznawca twierdzi, że

[...] analiza dyskursu powinna brać pod uwagę zarówno właściwości tekstu oraz wypowiedzi, jak i to, co zwykle określa się mianem kontekstu, a co obejmuje cechy sytuacji społecznej, które mogą systematycznie oddziaływać na strukturę komunikatu. Reasumując, przedmiot analizy dyskursu to wypowiedź i tekst w kontekście ${ }^{11}$.

Przez tytułowy „dyskurs o urokach” rozumiem zatem pisemne wypowiedzi dotyczące uroków: ich istnienia i oddziaływania oraz możliwości zwalczania, zawarte w wymienionych wcześniej poradnikach. Nadawcą komunikatów jest autorka publikacji oraz jej czytelnicy.

Jednym z najistotniejszych elementów dzisiejszego rosyjskiego dyskursu o urokach są wypowiedzi o charakterze informacyjnym, które przekonują, że uroki są powszechne (każdy może stać się ich ofiarą) i mają ogromny wpływ na ludzkie życie. Wypowiedzi tego typu obecne są w listach Stiepanowej:

Urok bywa różny. Można rzucić urok na biznes i człowiek straci cały majątek; można zauroczyć dziecko i będzie ono miało problemy ze snem. Można też zauroczyć tak mocno, że człowiek poważnie zachoruje i umrze ${ }^{12}$.

Jeśli po powrocie do domu ze spotkania (imprezy) czujecie się źle, to niewykluczone, że ktoś rzucił na was urok ${ }^{13}$.

\section{O powszechności uroków donoszą także czytelnicy poradników:}

Pewna nasza znajoma ciągle chwaliła naszą rodzinę: jakie macie dzieci, jaki piękny dom, jakiego mam wspaniałego męża [...] i ściągnęła nieszczęście. Teraz z mężem stale się kłócimy [...], dzieci nas nie słuchają, a ostatnio sąsiedzi zalali nam mieszkanie. Jestem pewna, że rzucono na nas urok. Pani Natalio, proszę powiedzieć, jak odczynić urok? Myślę, że wiele osób z zainteresowaniem to przeczyta ${ }^{14}$. Urodziłam zdrowe, silne, piękne dziecko i dopóki nie skończyło czterech lat, wszystko było dobrze. Pewnego razu, kiedy spacerowałam z synem w parku, podeszła do nas jakaś obdarta staruszka i zaczęła wychwalać mojego synka: jaki on zdrowy, silny, rumiany [...]. Wieczorem u syna pojawiła się wysoka temperatura [...]. Od tej pory dziecko stale choruje [...]. Czuję, że coś tu jest nie tak. Powiedziano mi, że na syna rzucono urok ${ }^{15}$.

zjawisko nie tylko literackie, ale także kulturowe (A. Gołębiowska-Suchorska, Od znachorki..., op. cit., s. 178-184). Na temat badań dyskursu ezoterycznego zob. S.I. Kuz'minskaâ, Nekotorye harakteristiki èzoteričeskogo diskursa, https://cyberleninka.ru/article/v/nekotorye-harakteristiki-ezotericheskogo-diskursa [dostęp: 1.06.2019]; Z. Novoženova, Strategii i taktiki rečevogo vozdejstviâ v èzoteričeskom diskurse, [w:] Perswazja językowa w różnych dyskursach, Ż. Sładkiewicz, A. Klimkiewicz (red.), Gdańsk 2017, t. 2, s. 13-23; V.M. Rozin, Ėzoteričeskij diskurs. Semantika sakral'nogo teksta, Moskva 2002; A. Sokół-Klein, Teksty ezoteryczne w mediach w świetle krytycznej analizy dyskursu, Łódź 2017.

${ }^{11}$ T. van Dijk, Badania nad dyskursem, [w:] Dyskurs jako struktura i proces, T. van Dijk (red.), thum. G. Grochowski, Warszawa 2001, s. 12.

12 N.I. Stepanova, Ot porči i sglaza ..., op. cit., s. 11-12. Jeżeli nie zaznaczono inaczej, wszystkie cytaty z języków obcych w przekładzie autorki artykułu.

${ }_{13}$ Eadem, 1777 novyh zagovorov..., op. cit., s. 192.

${ }^{14}$ Eadem, Ot porči i sglaza..., op. cit., s. 6-7.

${ }^{15}$ Ibidem, s. 11. 
Powyższe przykłady pokazują, że urok (zwykle poprzez nadmierne zachwalanie) może rzucić każdy człowiek, w dowolnej sytuacji, powodując tym samym różne nieszczęścia: chorobę, niepowodzenia rodzinne lub zawodowe, a czasem nawet śmierć. Co ciekawe, w poradnikach znajdujemy również wypowiedzi świadczące o tym, że urok można rzucić także na siebie samego. Stiepanowa wyjaśnia, jak do tego dochodzi: „Jeśli siebie pochwaliliście albo z czegoś się ucieszyliście (na przykład powiedzieliście sobie: «Dawno nie chorowałam» albo «Poprawiło mi się»), a potem okazało się, że sami rzuciliście na siebie urok, to trzeba specjalnym zaklęciem zamówić wodę, a potem umyć się nią"16.

Niektórzy czytelnicy potwierdzają posiadanie tej uciążliwej skłonności do „samourzekania":

Ciągle cierpię z powodu rzucania uroku na samą siebie! Jak tylko pomyślę o czymś dobrym (na przykład „dawno nie kłóciłam się z ukochanym”), to od razu przychodzi nieszczęście ${ }^{17}$.

Od dziecka jestem niebezpieczna w czynach i słowach. Mogę rzucić urok na każdego, nawet na własnego syna i samą siebie ${ }^{18}$.

Warto w tym miejscu przyjrzeć się sposobom rozumienia uroku jako działania magicznego. Myślę, że możemy zaryzykować stwierdzenie, że wiara w nasyłany przez pewnych ludzi zły czar (szczególnie za pośrednictwem „złego”, „urocznego” oka lub spojrzenia) jest ponadkulturowa i wciąż bardzo aktualna. O powszechności tego zjawiska pisała między innymi Grębecka: „Spotykałam się z tym wielokrotnie zarówno na Białorusi, jak i w Rosji. Spadający z roweru na widok etnografów mieszkaniec białoruskiej wsi mruczy «Sgłazili mienia». Złe oko jest też uznawane przez młode dziewczęta za najczęstszą przyczynę niepowodzeń miłosnych" 19 .

Na gruncie magii przekonanie, że za pośrednictwem spojrzenia, jakiemu towarzyszą negatywne emocje, można sprowadzić nieszczęścia, tłumaczone jest działaniem prawa kontaktu i możliwością przekazywania własnej siły magicznej przedmiotom, ludziom, zwierzętom i roślinom. Znane są także koncepcje, że urok może być wywoływany nieświadomie, bez udziału woli sprawcy. Taką skłonność posiadają zwłaszcza osoby, które matka w dzieciństwie zbyt pochopnie odstawiła od piersi, a także ludzie, których cechują jakieś anomalie dotyczące oczu (np. ich różny kolor lub zez $)^{20}$. W charakteryzowanym materiale najczęstszym sposobem definiowania uroku jest przeciwstawianie go innemu rodzajowi złego czaru, który w języku rosyjskim określany jest mianem porča. Oba rosyjskie określenia - sglaz i porča - wywodzą

${ }^{16}$ Ibidem, s. 9-10.

17 Ibidem, s. 10.

${ }^{18}$ Eadem, 1777 novyh zagovorov..., op. cit., s. 191.

19 Z. Grębecka, Stowo magiczne..., op. cit., s. 134.

${ }^{20}$ Zob. J.G. Frazer, Zlota gataź. Studia z magii i religii, tłum. H. Krzeczkowski, Warszawa 2002; M. Marczewska, Ja cię zamawiam, ja cię wypędzam ... Choroba. Studium językowo-kulturowe, Kielce 2012; V.F. Rajan, Banâ v polnoč'. Istoričeskij obzor magii i gadanij v Rossii, Moskva 2006; J. Talko-Hryncewicz, Zarys lecznictwa ludowego na Rusi Poludniowej, Kraków 1893; K. Moszyński, Kultura ludowa Stowian, t. 2: Kultura duchowa, Warszawa 1967; J. Sprenger, H. Kraemer, Młot na czarownice, Wrocław 2008. 
się z kultury ludowej i oznaczają szkodliwe oddziaływanie magiczne. I choć wywoływały one podobne skutki, to w mniemaniu ludu wyraźnie różniły się od siebie. Źródła etnograficzne donoszą, że porča zawsze oznaczała oddziaływanie celowe, zamierzone i przygotowane, sglaz zaś mógł zostać nasłany niezależnie od woli spraw$c y^{21}$. Podobne rozróżnienie znajdujemy w jednej z prac Uzdrowicielki:

W odróżnieniu od uroku porčy zawsze towarzyszy zła intencja - zaszkodzić, przenieść swoje nieszczęścia, choroby, problemy na innego człowieka [...]. Główne symptomy porčy są następujące: nagłe pogorszenie wyglądu zewnętrznego (szybkie starzenie się, plamy na twarzy), długotrwałe złe samopoczucie, którego przyczyn nie są w stanie wyjaśnić lekarze, niemająca uzasadnienia słabość i apatia, nagła i drastyczna utrata wagi lub tycie (przy prawidłowym sposobie odżywiania i dobrych wynikach badań), straszne sny, po których trudno dojść do siebie $[\ldots]^{22}$.

Kolejnym elementem współczesnego dyskursu o urokach są liczne wypowiedzi zawierające pogląd, że pomimo tego (a może właśnie przede wszystkim dlatego), iż naszym losem kierują niepojęte tajemne siły, możemy starać się na nie oddziaływać i podporządkowywać je swojej woli: zapobiegać negatywnym skutkom czarów, a w razie potrzeby skutecznie je neutralizować. Warto w tym miejscu odnotować, iż we wszystkich niemal kulturach system wierzeń opiera się na przekonaniu, że na początku jest siła, która - choć niewidoczna - jest wszędzie obecna i odczuwalna. Przekonanie o istnieniu mistycznej bezosobowej mocy, jakiej podlegają wszystkie zjawiska, zaowocowało wypracowaniem w każdym społeczeństwie specyficznego rodzaju zachowań. Obejmują one przestrzeganie kodeksu określonych nakazów i zakazów, wykonywanie rytualnych czynności oraz wypowiadanie formuł słownych. Ich celem jest podporządkowanie sobie wszechobecnej siły i wykorzystanie jej do własnych celów. Zabiegi te określa się zwykle mianem magii, na którą składają się trzy ważne elementy: przedmiot, czynność oraz słowo ${ }^{23}$. Stiepanowa często wyraża opinię, że za pomocą magii można mieć wpływ na wszystko, gdyż jest ona mocą, która podlega kontroli człowieka. W takim stanowisku wyraźnie widoczne są elementy myślenia magiczno-mitycznego, zgodnie z którym, jak zauważył Andrzej Wierciński:

[...] wykonawcą obrzędu magicznego może być właściwie każdy człowiek wierzący w jakimś stopniu w jego skuteczność [...]. Natomiast na miano maga, czarownika, czarodzieja, guślarza itd. zasługuje dopiero ten, kto trudni się magią profesjonalnie i jest przekaźnikiem jej tradycji swoim następcom. Musi to być osobnik o szczególnych predyspozycjach psychonerwowych i uzdolnieniach, który opanował znaczną wiedzę o otoczeniu i wiele umiejętności praktycznych ${ }^{24}$.

Uzdrowicielka, wykorzystując wypowiedzi o charakterze nakłaniającym do działania, przekonuje, że aby wieść dobre i szczęśliwe życie, wystarczy przejawić inicjatywę i podjąć konkretny krok - sięgnąć po jej książki:

${ }^{21}$ Zob. Sglaz, uroki, [w:] N.I. Tolstoj (red.), Slavânskie drevnosti. Ètnolingvističeskij slovar'v 5 tomah, t. 4, Moskva 2009, s. 597-598; Porča, ibidem, s. 178-179.

22 N.I. Stepanova, Ot porči i sglaza..., op. cit., s. 14-16.

${ }_{23}$ Zob. A. Engelking, Klątwa. Rzecz o ludowej magii stowa, Warszawa 2010; M. Buchowski, op. cit.

${ }^{24}$ A. Wierciński, Magia i religia. Szkice z antropologii religii, Kraków 1994, s. 107. 
Teraz nadeszła Wasza kolej, aby stać się panami swojego losu [...]. Otwórzcie książkę i zacznijcie działać. Wierzcie w siłę białej magii, a ona na pewno Wam pomoże! ${ }^{25}$

Ktoś może pomyśleć, że to wszystko są bajki... Cóż, pamiętam jak rok temu zwróciła się do mnie kobieta, która całe swoje życie zajmowała się nauką, a do magii odnosiła się sceptycznie. Jednak jej życie potoczyło się tak, że musiała uwierzyć w siłę czarów i zwrócić się do mnie o pomoc $[\ldots]^{26}$.

Aby zmotywować odbiorców do działania, syberyjska znachorka kreuje się na prawdziwą i wiarygodną, na kobietę z krwi i kości, „swojego człowieka”; wielokrotnie też (w materiałach drukowanych oraz internetowych) zachęca do kontaktu bezpośredniego. Mianuje siebie „wtajemniczoną”, posiadającą od pokoleń wiedzę magiczną, którą pragnie podzielić się z innymi dla dobra ludzkości. O sobie i swojej działalności pisze:

Odkąd pamiętam, moja babka Jewdokija uczyła mnie swojej sztuki i czasem nawet wydawało mi się, że ta nauka nie będzie miała końca. Wszystko jednak prędzej czy później się kończy. I tak... pewnego dnia otrzymawszy błogosławieństwo babki, przestałam być uczniem i stałam się dobrze wykształconym mistrzem [...]. Przekazuję Wam, moi drodzy, to, co mam najcenniejszego - niewyczerpane źródło mądrości i całą wiedzę mojego rodu. W książce znajdziecie to, czego chcieliście, bo przecież powstała ona na podstawie Waszych listów i próśb [...]. $\mathrm{Z}$ ogromną radością podzielę się z Wami swoją wiedzą i umiejętnościami ${ }^{27}$.

Ród wielkich uzdrowicieli Stiepanowych na przestrzeni wieków nie tylko przechowywał magiczne rytuały i zaklęcia, ale też szczodrze dzielił się nimi ze wszystkimi cierpiącymi ${ }^{28}$.

Zwracajcie się o pomoc i ja Wam pomogę ${ }^{29}$. Czytam i odpowiadam na Wasze listy [...]. Adres do korespondencji $[\ldots]^{30}$.

Kolejnym istotnym elementem rosyjskiego dyskursu o urokach czy, szerzej, o magii, jest to, że dzisiejsi magowie (znachorzy, wróżki) sami wychodzą do ludzi szukających pomocy ${ }^{31}$, chętnie również edukują wszystkich zainteresowanych. Omawiane

${ }^{25}$ N.I. Stepanova, Tajnâ̂ kniga znaharâ..., op. cit., s. 2.

${ }^{26}$ Eadem, Ot porči i sglaza..., op. cit., s. 3. Na marginesie należy zauważyć, że przytoczona wypowiedź stanowi przykład swoistego świadectwa nawróconego sceptyka, tj. człowieka, który przekonał się do magii dopiero pod wpływem jakichś niewyjaśnionych zjawisk, dotykających go osobiście.

${ }^{27}$ Eadem, 1777 novyh zagovorov..., op. cit., s. 3-7.

${ }^{28}$ Eadem, Tajnaâ kniga znaharâ..., op. cit., s. 2.

${ }^{29}$ Eadem, Zagovory sibirskoj celitel'nicy..., op. cit., s. 6.

${ }^{30}$ Eadem, Ot porči i sglaza..., op. cit., s. 278.

${ }^{31}$ Obejmuje ona nie tylko poradniki i zbiory zaklęć, ale także amulety, szkolenia, kursy. Stiepanowa oferuje również preparaty lecznicze i upiększające, które - jak twierdzi - najlepiej działają w połączeniu z jej zaklęciami. Uzdrowicielka szczegółowo pisała o tym w jednej z książek. Zob. Vnimaniû bol'nyh, [w:] N.I. Stepanova, Ot porči i sglaza ..., op. cit., s. 275-277. Należy podkreślić, że rozmaite usługi magiczne (w tym również świadczone na odległość) są powszechne także w internecie. Krótką charakterystykę kilku witryn należących do współczesnych rosyjskich magów przedstawiłam w artykule: Wspótczesne rytuały magiczne w Internecie - Przyczynek do analizy rosyjskiego dyskursu magicznego, [w:] Język - obraz - dyskurs, M. Cieszkowski, A. Kapuścińska, J. Szczepaniak (red.), Bydgoszcz 2017, s. $37-45$. 
poradniki zawierają obszerne fragmenty o charakterze dydaktyczno-informacyjnym. Nasza autorka przekonuje o skuteczności magii i zachęca do uczenia się oraz stosowania różnorakich praktyk magicznych:

Dyskusje o tym, czy istnieją w przyrodzie takie cuda jak magia, czary i jasnowidztwo, były, są i zawsze będą. Ja nigdy nie miałam takich wątpliwości, gdyż od wczesnego dzieciństwa, każdego dnia i miesiąca mogłam obserwować niewiarygodne cuda $[\ldots]^{32}$. W Biblii, a także w latopisach dużo mówi się o groźnej broni - o nauce, która zdolna jest czynić cuda. Nauka, którą wspólnie zglębimy, da Wam niezwykłą i ciekawą wiedzę [...]. Ten, kto dotrwa ze mną do końca, nauczy się wszystkiego: leczenia, przedłużania życia i młodości $[\ldots]^{33}$. Jeśli nijak nie możecie nauczyć się na pamięć zaklęcia, to przepiszcie je na karteczkę i czytajcie z niej; najważniejsze - nie pomylić się $e^{34}$.

Jako skuteczny sposób na pozbycie się (odczynienie, odwrócenie) uroku Stiepanowa proponuje zwykle rytuały i zaklęcia znane w kulturze ludowej (o których pisałam w monografii poświęconej językowi zaklęć rosyjskich ${ }^{35}$ ). Należy odnotować, że uroki - występujące $\mathrm{w}$ tradycji wschodniosłowiańskiej pod różnymi nazwami: urok, prizor, prikos, sglaz, očes - uważane są za jedną z najczęstszych przyczyn wszelakich nieszczęść, w tym także chorób (szczególnie dziecięcych). Poświadczają to źródła z XIX wieku oraz współczesne badania terenowe. W wielu pracach etnograficznych rozdział poświęcony urokom jest dość obszerny i zawiera wiele ciekawych informacji o czarach tego typu ${ }^{36}$. Okazuje się, że najpopularniejszym sposobem walki z czarami nasyłanymi jest ich zmycie. Czynności tej najczęściej towarzyszą formuły słowne, zawierające różnorodne strategie werbalnego oddziaływania na rzeczywistość, jak np. odesłanie nieszczęścia do źródła, porównanie (przejaw magii

32 N.I. Stepanova, 1777 novyh zagovorov..., op. cit., s. 3.

33 Eadem, 909 zagovorov..., op. cit., s. 6.

${ }^{34}$ Eadem, Ot porči, sglaza, i proklâtiâ..., op. cit., s. 8.

35 J. Rybarczyk-Dyjewska, Język jako narzędzie magii. Na przykładzie zaklęć rosyjskich, Kraków 2013.

${ }^{36}$ Zob. ibidem, s. 35-41. W zbiorze Władimira Prokopjewicza Anikina przeczytamy np. „Urok można rzucić na każdego. Bydło też można urzec i ono wtedy ciężko choruje i na człowieka można rzucić urok i on wtedy ziewa, i ciągle chce mu się spać. A na małe dzieci to w ogóle nie można patrzeć, je trudno wyleczyć z uroku. Trzeba wodę trzykrotnie zamówić i wylać, wtedy może pomoże. Dorośli łatwiej znoszą urok" (Russkie zagovory i zaklinaniâ. Materialy fol'klornyh èkspedicij 1953-1993 gg., V.P. Anikin [red.], Moskva 1998, s. 79). Informatorzy donoszą, że skuteczną terapią uwalniającą od uroku jest wykorzystanie wody (często w połączeniu z solą), którą chorego należy umyć lub ochlapać. Czynnościom towarzyszy magiczna formuła werbalna: „A od uroku ona (kobieta, babka) myła. Kiedy dziecko było zauroczone, przynosili je do tej kobiety. Ta wrzucała do wody dziewięć tlących się węgielków i szczyptę soli i mówiła coś do siebie, a potem myła, ochlapywała z trzech łyżek, dała się napić i dziecko się uspokajało i nie płakało w ogóle"(ibidem, s. 76). Podobne opisy znajdujemy w kolekcji zaklęć Leonida Nikołajewicza Majkowa z XIX w.: „,Trzeba wziąć wodę, którą będzie się oblewać chorego. Wstałem ja, sługa boży (imię), przeżegnawszy się poszedłem [...]. I tak na słudze bożym (imię) nie trzymałyby się uroki i inne złe (obmawiające) słowa, postrzały od wiatru i nocne strachy na wieki wieków. Amen" (L.N. Majkov [red.], Velikorusskie zaklinaniâ, Sankt-Peterburg 1994, s. 92). Zob. także: A. Vetuhov, Zagovory, zaklinaniâ, oberegi i drugie vidy narodnago vračevaniâ, osnovannye na vere v silu slova, Varšava 1907; M. Zabylin, Russkij narod, ego obyčai, obrâdy, predaniâ, sueveriâ, Moskva 1880. Na temat popularnego we wschodniosłowiańskiej tradycji ludowej motywu zmywania chorób pisała Tatiana Aleksiejewna Agapkina (eadem, Vostočnoslavânskie lečebnye zagovory v sravnitel'nom osvê̂enii. Sûžetika i obraz mira, Москва 2010, s. 231-233. 
sympatycznej), zdania alogiczne, a także przywołanie na pomoc postaci sakralnych (Jana Chrzciciela, Matki Boskiej) czy zastosowanie wyrażeń performatywnych:

Poproście sąsiadów z trzech różnych mieszkań lub domów o szczyptę soli. Wrzućcie tę sól do rondelka z wodą, przeczytajcie nad nią zaklęcie i umyjcie się. Słowa zaklęcia są takie: „Szedł dwugłowy zły czarownik [glazun], żebrał, przeniósł się na moje ciało, przyleciał bez skrzydeł, usiadł na mojej duszy. Skąd ty, uroku, przyleciałeś, tam i leć. Kamień rodzi kamień, woda boża i sól zwyciężą. Tak jak palec serdeczny [bezymânnyj] nie ma imienia, tak i krzyż boży nie ma uroku, i tak od teraz nie ma też uroku na mnie, służebnicy bożej (imię). W imię Ojca, i Syna, i Ducha Świętego. Teraz i zawsze, i na wieki wieków. Amen"37.

Chorego sadza się na progu drzwi wejściowych i przelewając wodę ze szklanki do szklanki, czyta się następujące zaklęcie: „W imię Ojca, i Syna, i Ducha Świętego. W pierwszym podejściu, w dobrym czasie, wymawiam ja, zamawiam: od uroku czarnego, od żeńskiego i męskiego, od minutowego i półgodzinnego [...]. Idź uroku tam, gdzie stare wrota, gdzie zgubili od nich klucz, gdzie dusze swoje sprzedali. Tam tobie uroku żyć i na zawsze być. Słowo pójdź do słowa, czyn do czynu. Amen. Amen. Amen"38.

Zaprezentowany materiał językowy pokazał, że mimo rozwoju cywilizacyjnego wiara w niewyjaśnione naukowo zjawiska jest wciąż żywa i aktualna. Różnorodne przejawy ezoteryzmu są obecne i popularne w dzisiejszym, przepełnionym nowoczesną technologią świecie. Praktyki magiczne proponowane przez Stiepanową w wielu aspektach wyraźnie nawiązują do wierzeń obecnych w kulturach tradycyjnych. Dlatego też - jak zauważa Andrzej Szyjewski - możemy na nie spojrzeć przede wszystkim jak na „kompleks ilustrujący sposoby interpretacji rzeczywistości”39.

Najistotniejszym elementem rosyjskiego dyskursu o urokach są wypowiedzi zawierające przekonanie, że życiem ludzkim sterują nadnaturalne siły, nad którymi - za pomocą odpowiednich narzędzi - można zapanować. Przeświadczenie o sprawczej mocy czarów ujawnia się szczególnie wyraźnie w sytuacji zagrożenia (np. problemów zdrowotnych czy niepowodzeń osobistych), która postrzegana jest jako wynik rzuconego uroku. Na marginesie warto odnotować, że współczesne rosyjskie czarownictwo wpisuje się tym samym w szerszy kontekst metod redukcji cierpienia. Łatwiej przecież kogoś lub coś obarczać odpowiedzialnością, niż przypisać sobie winę za poniesioną klęskę ${ }^{40}$. Pogląd o możliwości nadnaturalnego oddziaływania na

${ }^{37}$ N.I. Stepanova, Ot porči i sglaza..., op. cit., s. 7.

38 Ibidem, s. 11-12.

${ }^{39}$ A. Szyjewski, Etnologia religii, Kraków 2001, s. 90. Zob. także: A. Wierciński, Magia i religia..., op. cit., s. 103-109.

${ }^{40}$ Zjawisko to jest bardzo stare. Pisał o nim twórca etnografii czarownictwa Edward E. Evans-Pritchard, który badając afrykańskie plemię Azande, zauważył, że „najczęstsza z odpowiedzi o winę brzmi: nieszczęściu winne są czary” (E.E. Evans-Pritchard, Czary, wyrocznie i magia u Azande. Wersja skróco$n a$, tłum. S. Szymański, Warszawa 2008, s. 16). Ciekawe i zbieżne z powyższymi spostrzeżenia na temat dyskursu związanego z urokami poczyniła Jeanne Favret-Saada. Przez prawie trzy lata prowadziła ona badania terenowe na prowincji francuskiej. Rezultatem tych eksploracji są publikacje (z lat 70. XX w.), w których autorka nie tylko pokazuje ludzi niejako skazanych na rozwiązywanie problemów za pomocą sposobów magicznych, ale również dzieli się swoimi doświadczeniami uczestnictwa w wiejskim odczynianiu uroków. Wskazuje także na wiele problemów dotyczących badania skomplikowanego zjawiska, jakim niewątpliwie jest wiara w uroki; zastanawia się np. w jaki sposób zaangażowanie emocjonalne wpływa na konstruowanie dyskursu na temat czarownictwa. Zob. J. Favret-Saada, Śmiercionośne słowa, 
rzeczywistość, prezentowany przez czytelników Natalii Stiepanowej, mocno determinuje charakter jej twórczości. Syberyjska Uzdrowicielka zachęca do korzystania ze swojej bogatej oferty wtajemniczenia, przekonując, że wykonawcą obrzędu może być każdy, a jednocześnie tworzy interesujący dyskurs o magii. Podsumowując, można zauważyć, że magia wcale nie znika z naszego życia; wręcz przeciwnie - rozwija się i dopasowuje do realiów współczesnego świata. Staje się coraz częściej i wyraźniej obecna w otaczającej nas rzeczywistości, a towarzyszący jej dyskurs - wielowątkowy, urozmaicony i skomplikowany - niewątpliwie wart jest dalszych badań jako istotna część kultury popularnej.

\section{Bibliografia}

\section{Źródła}

Stepanova N.I., 1777 novyh zagovorov sibirskoj celitel'nicy, Moskva 2013.

Stepanova N.I., 909 zagovorov sibirskoj celitel'nicy, Moskva 2011.

Stepanova N.I., Ot porči i sglaza, Moskva 2016.

Stepanova N.I., Ot porči, sglaza, i proklâtiâ, Moskva 2017.

Stepanova N.I., Tajnaâ kniga znaharâ, Moskva 2017.

Stepanova N.I., Zagovory sibirskoj celitel'nicy, Moskva 2011.

Stepanova N.I., Zaŝitnaâ kniga - kalendar'. Zagovory i oberegi na každyj den', Moskva 2008.

\section{Literatura przedmiotu}

Agapkina T.A., Vostočnoslavânskie lečebnye zagovory v sravnitel'nom osveŝenii. Sûžetika i obraz mira, Москва 2010.

Barceló J.L., Czarna magia w XX wieku, tłum. Z. Siewak-Sojka, Warszawa 1991.

Brzozowska-Krajka A., Między magią a religia. O modlitewkach ludowych, [w:] Folklor-sacrumreligia, J. Bartmiński, M. Jasińska-Wojtkowska (red.), Lublin 1995, s. 183-200.

Buchowski M., Magia. Jej funkcje i struktura, Poznań 1986.

Burszta W.J., Od mowy magicznej do szumów popkultury, Warszawa 2009.

Crowley A., Magija w teorii i praktyce, thum. M. Uniejski, Katowice 1998.

Dijk T. van, Badania nad dyskursem, [w:] Dyskurs jako struktura i proces, T. van Dijk (red.), thum. G. Grochowski, Warszawa 2001, s. 9-44.

Encyklopedia popularna PWN, Petrozolin-Skowrońska B. (red.), Warszawa 1994.

Engelking A., Klątwa. Rzecz o ludowej magii słowa, Warszawa 2010.

Ermolina Û.V., Magiâ kak kul'turno-religioznyj fenomen, avtoreferat dissertacii na soisk. Učënoj stepeni kandidata filosofskih nauk, Orël 2009, https://www.dissercat.com/content/magiya-kak-kulturno-religioznyi-fenomen/read [dostęp: 1.06.2019].

Evans-Pritchard E.E., Czary, wyrocznie i magia u Azande. Wersja skrócona, tłum. S. Szymański, Warszawa 2008.

Favret-Saada J., Odczynianie uroków, tłum. K. Marczewska, Warszawa 2014.

zabójcze uroki, thum. K. Marczewska, Warszawa 2012; eadem, Odczynianie uroków, thum. K. Marczewska, Warszawa 2014. Z publikacji rosyjskich na uwagę zasługuje przede wszystkim praca Olgi Borisownej Christoforowej. Rosyjska badaczka, analizując mechanizmy warunkujące wiarę współczesnych Rosjan w magię, podkreśla, iż w dyskursie magicznym dominuje społeczna etiologia nieszczęść, nawet w przypadku braku rzeczywistego konfliktu międzyludzkiego, w związku z czym zwalczanie kryzysów oznacza walkę z agresorem zewnętrznym, co nie wymaga od „ofiary” dużego nakładu sił: O.B. Hristoforova, Kolduny i žertvy..., op. cit., s. 47, 102-103. 
Favret-Saada J., Śmiercionośne stowa, zabójcze uroki, tłum. K. Marczewska, Warszawa 2012.

Frazer J.G., Złota gałaź. Studia z magii i religii, tłum. H. Krzeczkowski, Warszawa 2002.

Gołębiowska-Suchorska A., „Poproś wodę o pieniadze”. Tradycja znachorska we wspótczesnych poradnikach magicznych $w$ Rosji, „Lud. Organ Polskiego Towarzystwa Ludoznawczego i Komitetu Nauk Etnologicznych PAN" 2015, t. 49, s. 209-230.

Gołębiowska-Suchorska A., Od znachorki do autorki. Rosyjska tradycja znachorska we wspótczesnych poradnikach magicznych, Bydgoszcz 2016.

Grębecka Z., Stowo magiczne poddane technologii. Magia ludowa w praktykach postsowieckiej kultury popularnej, Kraków 2006.

Grom B., Ezoteryzm - nowa nadzieja?, tłum. U. Popławska, Kraków 2006.

Hristoforova O.B., Kolduny i žertvy. Antropologiâ koldovstva v sovremennoj Rossii, Moskva 2010.

Kowalczewska A., Ezoteryka na sprzedaz, Warszawa 2001.

Kuz'minskaâ S.I., Nekotorye harakteristiki èzoteričeskogo diskursa, https://cyberleninka.ru/article/ v/nekotorye-harakteristiki-ezotericheskogo-diskursa [dostęp: 1.06.2019].

Majkov L.N. (red.), Velikorusskie zaklinaniâ, Sankt-Peterburg 1994.

Marczewska M., Ja cię zamawiam, ja cię wypędzam... Choroba. Studium językowo-kulturowe, Kielce 2012.

Moszyński K., Kultura ludowa Słowian, t. 2: Kultura duchowa, Warszawa 1967.

Mihaleva O.L., Političeskij diskurs. Specifika manipulâtivnogo vozdejstviâ, Moskva 2009.

Novoženova Z., Strategii i taktiki rečevogo vozdejstviâ v èzoteričeskom diskurse, [w:] Perswazja językowa $w$ różnych dyskursach, Ż. Sładkiewicz, A. Klimkiewicz (red.), Gdańsk 2017, t. 2, s. 13-23.

Rajan V.F., Banâ v polnoč’. Istoričeskij obzor magii i gadanij v Rossii, Moskva 2006.

Rozin V.M., Ėzoteričeskij diskurs. Semantika sakral'nogo teksta, Moskva 2002.

Russkie zagovory i zaklinaniâ. Materialy fol'klornyh èkspedicij 1953-1993 gg., V.P. Anikin (red.), Moskva 1998.

Rybarczyk-Dyjewska J., Język jako narzędzie magii. Na przyktadzie zaklęć rosyjskich, Kraków 2013.

Rybarczyk-Dyjewska J., Współczesne rytuały magiczne w Internecie. Przyczynek do analizy rosyjskiego dyskursu magicznego, [w:] Język-obraz - dyskurs, M. Cieszkowski, A. Kapuścińska, J. Szczepanik (red.), Bydgoszcz 2017, s. 37-45.

Rytualny chaos. Studium dyskursu publicznego, M. Czyżewski, S. Kowalski, A. Piotrowski (red.), Warszawa 2010.

Slavânskie drevnosti. Ètnolingvističeskij slovar'v 5 tomah, Tolstoj N.I. (red.), t. 4, Moskva 2009.

Sokół-Klein A., Teksty ezoteryczne w mediach w świetle krytycznej analizy dyskursu, Łódź 2017.

Sprenger J., Kraemer H., Młot na czarownice, Wrocław 2008.

Subbotskij E.V., Neuničtožimost'volšebnogo: Kak magiâ i nauka dopolnâût drug druga v sovremennoj žizni, Moskva-Berlin 2015.

Szyjewski A., Etnologia religii, Kraków 2001.

Talko-Hryncewicz J., Zarys lecznictwa ludowego na Rusi Poludniowej, Kraków 1893.

Tambiah S.J., Magia, nauka, religia a zakres racjonalności, tłum. B. Hlebowicz, Kraków 2007.

Tarnavskyi V., Dzieci swoich czasów. Ruchy młodzieżowe w Rosji a zmiany kulturowe po upadku ZSRR, Warszawa 2007.

Vetuhov A., Zagovory, zaklinaniâ, oberegi i drugie vidy narodnago vračevaniâ, osnovannye na vere $v$ silu slova, Varšava 1907.

Weber M., Szkice z socjologii religii, tłum. J. Prokopiuk, H. Wandowski, Warszawa 1995.

Wierciński A., Magia i religia. Szkice z antropologii religii, Kraków 1994.

Zabylin M., Russkij narod, ego obyčai, obrâdy, predaniâ, sueveriâ, Moskva 1880. 


\section{Strony internetowe}

http://www.magia21.ru [dostęp: 1.06.2019].

https://www.ozon.ru/category/ezoterika-i-spiritizm-40016/?nonfictionbookgenre=135749 [dostęp:

1.06.2019].

http://www.elena-mag.ru/uslugi/ [dostęp: 1.06.2019]. 